\title{
Method of Payments in the Merger and Acquisitions Transaction: The Case of Saudi Arabia
}

\author{
Nadisah Zakaria ${ }^{1, *}$, Kamilah Kamaludin $^{2}$ and Alya Alkhalifa ${ }^{1}$ \\ ${ }^{1}$ Department of Finance, College of Business, Prince Sultan University, Saudi Arabia \\ ${ }^{2}$ Department of Finance, University Malaya-Wales, Malaysia
}

\begin{abstract}
The performance of mergers and acquisitions companies has been broadly investigated in diverse advanced share markets primarily in the US and UK economies. However, little evidence has been found in an emerging market like Saudi Arabia. For this reason, this study examines the long-run share performance of acquirer' companies listed on the Saudi Arabia Stock Exchange (Tadawul) from $1^{\text {st }}$ January 2000 to $31^{\text {st }}$ August 2017. Using the buy-and-hold abnormal return method, the present study finds that the acquirer companies' shares for the cash payment method continues to outperform their counterparts of non-cash payment against the equal-weighted and value-weighted indexes. The presence of abnormal return opportunities that may be exploited by investors in the three-year holding period following the completion of M\&A events might provide valuable insight to individual and institutional investors. As there is no national evidence on share performances of acquirer's companies over the long-run period, the present findings add to a growing body of M\&A literature.
\end{abstract}

Keywords: Mergers, acquisitions, short-and-long run performance, Saudi Arabia.

\section{INTRODUCTION}

Mergers and acquisitions have been widely studied area from diverse perspectives and disciplines. M\&A often involves huge investment for firms, and its success can boost growth, employment and sustainable development for the market and economy of a nation. M\&A transactions posit positive synergies from economies of scale and scope, best practice and knowledge sharing of capabilities and opportunities which leads to wealth creation for shareholders. Nevertheless, often than not, M\&A ends in failure and caused wealth destruction instead. Because of this, M\&A becomes a highly studied area to better understand the characteristics, reasons and factors to ensure a successful M\&A is appraised and realized. From the corporate finance perspective, studies involving M\&As investigates the effects of different types (hostile vs friendly), characteristics (size, cross border vs local acquisition), timing and methods of payment on acquirers' short-term and long-term performance. As such, this study examines the effects of the methods of payment in mergers and acquisition activities on the long-term share performance of the acquiring companies between 1998 to 2017 in the Kingdom of Saudi Arabia. Empirical evidence suggests that different types of financing decisions signal information about the firm's value and subsequently leads to different implication to the share performance. While studies on mergers and acquisitions in the

*Address correspondence to this author at the Department of Finance, College of Business, Prince Sultan University, Saudi Arabia; Tel: +966 0554923574; Fax: +966 114948888; E-mail: nzakaria@psu.edu.sa developed markets have been extensive (Agrawal \& Jaffe, 2000; Dutta \& Jog, 2009; Dutta, Saadi, \& Zhu, 2013), little (or nil) evidence has been found in an emerging market like Saudi Arabia (Dowling \& Vanwalleghem, 2018). In fact, to the best of our knowledge, this study is the first in studying the long run share performance of post-acquisition in Saudi Arabia. Saudi Arabia is becoming an important player in the global economy. While its capital market is still in its infancy, it is gaining wider interests and attention from international investors and institutions to invest in this region.

Notably, the formation of Tadawul has been approved on $19^{\text {th }}$ March 2007 and to date is the only sole entity authorized in Saudi Arabia to act as Securities Exchange and the Securities Depository Centre (Tadawul.com). Saudi Arabia's Stock Exchange experienced a major change in most recent years. On $1^{\text {st }}$ June 2015, the Capital Market Authority (CMA) allowed foreign financial institutions to buy and sell shares in companies listed on Tadawul as an effort to extend its market participants. Previously, international investors had limited access to Saudi Stock Exchange through instruments such as swaps and they only owned $7.74 \%$ of the Saudi Arabian share market's value (Bloomberg, 2016). With this dramatic changes, one essential question in the present study is whether the share market is efficient in Saudi Arabia. The Efficient Market Hypothesis (EMH) suggests that share prices are unbiased estimates of their intrinsic values (Fama, 1970). All new information will be quickly adjusted and incorporated in the current share price, hence making any above-average returns impossible. 
While this idea has been widely debated and challenged worldwide, very limited findings are reported for Saudi Arabia. As such, this study aims to examine the long-run share performance of acquirer' companies listed on the Saudi Arabia Stock Exchange (Tadawul) from $1^{\text {st }}$ January 2000 to $31^{\text {st }}$ August 2017. Using the buy-and-hold abnormal return method, the present study finds that the acquirer companies' shares for the cash payment method continues to outperform their counterparts of non-cash payment against the equal-weighted and value-weighted indexes. This study provides opportunity to enhance the limited understanding about the market efficiency of the Saudi capital market. This study investigates whether the news concerning merger and acquisition events particularly in the case of method of payments would provide pockets of inefficiency at a margin that can be exploited by both individuals and institutional investors.

\section{LITERATURE REVIEW}

There are three methods of payment to finance M\&A activities; stock, cash and combination of both. The payment method provides different implication on the short and long-term post-acquisition performance. Researchers argue that financing M\&A activities using stocks send a negative signal to the market. This argument is drawn based on signalling theory and information asymmetry arguments where acquiring firms are willing to render their shares as basis of payment when they feel their shares are overvalued (Berkovitch \& Narayanan, 1990; Myers \& Majluf, 1984). However, share payments caused dilution of acquirer's outstanding shares and because of that managerial remuneration cannot be tied to their investment decision. Such agency costs reduce synergies expected from M\&A, and once market becomes aware of these issues, share prices will fall following the announcement.

On the contrary, financing M\&As through cash provides positive signal to the acquisition firm. Cash payment indicates that the acquisition will be financed through long-term debt. Long-term debt requires religious payment of principal and interests to the banks. This implies the acquirer is confident that they would generate high enough returns for debt repayment. It is also argued that long-term debt repayment provides motive for improvement of financial performance through creation of operational efficiency and synergies between the acquirers and target firms.

The methods of payment also indicate the nature of the takeovers. Cash payment is usually used in hostile acquisition, where time is an essence and the acquiring companies need to complete the M\&A deal as soon as possible as the target firm is coveted by competing bidders. In addition, cash offers signal the high value of the target firm, and because of that the acquirer is trying to pre-empt other competition (Fishman, 1989).

Although it has been implied that stock financed acquisitions send out negative signal of overvaluation of the acquirers' shares, which subsequently leads to negative share price performance; the evidence is mixed on this matter. Many studies that were conducted in the developed countries like the US and UK documented evidence that support the signaling theory and information asymmetry argument by Myers and Majluf (1984) (see Franks, Harris, and Mayer (1987), Franks, Harris, and Titman (1991) and Loughran and Vijh (1997), Travlos (1987), Hansen (1987), and Berkovitch and Narayanan (1990) amongst others)

Franks et al. (1987) argue that cash financed acquisitions fare better than stock financed acquisitions in their international comparisons between the US and the UK market. Franks et al. (1987) compare the postacquisition share price performance of the UK and the US bidder. In the US sample, there is clear differences of post-acquisition performance between all cash and all equity bids. Franks et al. (1987) find that all cash bids outperform all equity bidders after merger. They observed similar occurrences in the UK market where all equity offers had significantly worse performance than all cash offers. Nonetheless, Franks et al. (1987) are not entirely convinced that the post-acquisition performance of stock-financed acquisitions was less than zero. They argued that stock financed acquisitions may have suffered abnormal negative return due to the benchmark employed. Alternatively, they found a small positive post acquisitions returns when employing the capital asset pricing model. This implies that their findings were sensitive to the benchmark used. Additionally, Franks et al. (1987) do not find any evidence that a country's taxation is a determinant for the financing method of mergers and acquisitions in the UK.

Loughran and Vijh (1997) in their study of 947 companies in the US market during 1970-1989 create two ways classification based on methods of payment (cash vs equity) and mode of acquisition (mergers vs tender offers) to find the determinants of long-term post-acquisition performance. They found negative abnormal return for equity financed mergers but 
positive abnormal return for cash-financed tender offers, and these differences were significant from zero. By contrast, the abnormal return from equity financed tender offers and cash-financed mergers were not significantly different from zero. Finally, Loughran and Vijh (1997) compared the differences between the abnormal return in stock-financed mergers with stockfinanced tender offers but found that they were not significantly different from zero hence concluding that the differences of performance results from the mode of payment rather than mode of acquisition.

Interestingly, Franks et al. (1991) while noting that cash financed acquisitions generated positive abnormal return and stock financed acquisitions generated negative abnormal return, their findings somehow indicated that these returns are not significantly different from zero. In their study of 399 US takeovers between 1975-1984, Franks et al. (1991) found small positive performance of cash-bidders $(0.26 \%$ per month) and small negative performance for all equity bidders $(-0.17 \%$ per month) which were not statistically significant, hence rejecting the notion that the methods of payment were the determinants of abnormal return in post-acquisition performance. They concluded that the earlier findings of negative returns in postacquisition performance may be resulting from benchmark error rather than systematic mispricing at the time of the acquisition, recasting similar doubt earlier by Franks et al. (1987).

Except for Franks et al. (1991) that did not find evidence of underperformance following acquisitions, other studies (see Andrade, Mitchell, and Stafford (2001), Andre, Kooli, and L'Her (2004) and Fuller, Netter, and Stegemoller (2002)) have concluded in support of Franks et al. (1987), Loughran and Vijh (1997) and Myers and Majluf (1984). For example, Andrade et al. (2001) in their study of 267 mergers and acquisitions that were taking place in the Canadian market between 1980 and 2000 found that Canadian acquirers significantly underperform in the long-run. However, a recent evidence on the Canadian market by Dutta and Jog (2009) contradicted Andrade et al. (2001)'s findings. Dutta and Jog (2009) using a larger and more recent sample, studied 1300 firms in the Canadian market between 1993 to 2002. In order to avoid potential methodological criticisms and concerns, Dutta and Jog (2009) used variety of methodological choices to reinforce the robustness of their findings. Nonetheless, they still did not find negative abnormal long-term returns for the acquirers even after mitigating for the potential methodological concerns.
While many studies suggested that post acquisition performance of cash-financed acquisitions exceeded stock-financed acquisitions, there were studies that documented otherwise. These studies found evidence that suggested stock financed acquisitions gain positive abnormal return significantly exceeding cash financed acquisitions (Moeller, Schlingemann, and Stulz (2005); Ismail (2008); and Goergen and Renneboog (2004). A recent study from the Chinese market reiterated this finding. Yang, Guariglia, and Guo (2017) studied all Chinese acquisitions between 1988 to 2015. Their sample included 3,966 acquisitions events from 1,152 unique acquirers. Yang et al. (2017) found that cash acquisitions underperformed stock acquisitions. To make sense of their findings, they analyzed and compared the pre-acquisition operating performance between the cash-financed and stock-financed bidders. Their analysis indicated that the pre-acquisition operating performance was actually higher for the cash-financed compared to the stock financed bidders. As such, they argued that post-acquisition underperformance of cash-financed bidders may be substantiated by (1) management discretion to undertake low-return mergers for their private interests considering their substantial cash accumulation following good operating performance; (2) limited investment opportunities and lower opportunity costs of cash holdings, firms used M\&As as a way of spending excess cash. In light of their finding, they argued such occurrence is plausible given China's weak corporate governance environment.

The review on the long-run post acquisition share performance, thus far still indicates that the empirical evidence is still mixed and remains as one of the puzzling phenomena of the finance literature (Agrawal $\&$ Jaffe, 2000). The following section discusses the data and research methodology employed followed by the discussion of the results and findings and subsequently conclusion of the study.

\section{DATA AND RESEARCH METHODOLOGY}

\subsection{Sample Selection}

To date, there is no evidence pertaining to these issues have been investigated, since Saudi Arabia market is younger and less matured compared to the advanced market. Hence, this study sought to fill this gap in the M\&A literatures. The initial identities of 72 completed $M$ \& $A$ events in the Kingdom of Saudi Arabia were obtained from the Bloomberg Professional Services (Bloomberg), one of the primary and 
authoritative financial information providers. The final sample selection of acquirer companies satisfy the following criteria: (1) acquirers' country of origin is Saudi Arabia; (2) listed on Tadawul; (3) completed M $\& A ;(4)$ deals are mergers and acquisitions of majority interest only; (5) the exclusion of withdrawn or pending $M \& A ;(6)$ the exclusion of companies from Financial and REIT Fund industry sectors.; (7) companies with several M\&A during the period are included; and (8) the availability of monthly returns data on the Bloomberg for up to three years following the listing date.

This study incorporates 24 acquisitions using only cash while the remaining of 19 acquisitions were made with a mixture of equity and cash. To analyze the oneto-three-years post M\&A performance, we required 36 monthly returns data for the acquiring companies from January 2000 to December 2014. Though the last formation of portfolio in 2014, the study employed the one, two and three years Buy-and-Hold-Abnormal Return approach to evaluate the performance of value shares for the year 2015, 2016 and 2017. If the study end at 2017, data for the performance of value shares of 2018, 2019 and 2020 have to be measured. Therefore, the period used in the present study is from 2000 through 2017.

The monthly closing prices of acquirer companies were gathered from the Bloomberg to compute the 36 monthly buy-and-hold returns for the sample companies. The monthly buy-and-hold returns for each acquirer company were then compared with the monthly buy-and-hold market returns to derive the market-adjusted abnormal returns following the completion month of the M\&A event.

The study applies two market indices: equal-weight Index (EWI) and value weight index (VWI). Both benchmarks include all companies on the Tadawul. Equal weight index gives the same weight or importance to each share listed on the Tadawul. Similarly, using this approach, the smallest companies are also given equal weight to that of the largest companies. On the other hand, value weight index refers to each share listed on the Tadawul that is weighted according to the total market value of their outstanding shares. In other words, the weights of individual shares are proportionate to their market capitalization. The market returns for SAS-EWI and SAS-VWI of $n$ share in event day $t$ are calculated as follows:

$$
R_{m t}=\sum_{j=1}^{n j} W_{j t} R_{j t}
$$

Where, $R_{m t}$ is the daily/monthly market returns in period $t, W_{j t}$ is the weight given, $1 / N_{t}$ is used to calculate equal-weighted market returns (as in SASEWI) and $M V_{t} / \sum M V_{t}$ is used to compute valueweighted market returns (as in SAS-VWI). $M V_{t}$ is the market capitalisation of individual companies in period $t$. According to Xiao and Arnold (2008), both EWI and VWI allow researchers to analyze the sensitivity of the results to the choice of the market. As at $31^{\text {st }}$ December 2017, there are 187 companies listed on the Tadawul (Bloomberg, 2017). To develop EWI and VWI indices, the share price data both daily and monthly for each company traded in the Saudi Arabia Stock Exchange (Tadawul) was collected from the Bloomberg database.

\subsection{Long-Run Return: Buy-and-Hold Abnormal Returns}

This research adopts the buy-and-Hold Abnormal Return method to evaluate the share return performance of acquirer companies over the long-run period (see Myers and Majluf (1984), Fishman (1989), Franks et al. (1987), Andrade et al. (2001), and Loughran and Vijh (1997) and Fuller et al. (2002)). The analysis of the return focused on abnormal return, which is defined in this context as the difference between the actual return and the expected return of individual shares in the portfolios. Despite Lyon, Barber, and Tsai (1999) providing a reminder regarding the use of buy-and-hold abnormal returns (BHAR), extensive literature supports the use of the BHAR method as it tackles the effect of compounding better than does cumulative abnormal return (CAR; Ritter (1991); Barber and Lyon (1997). Fama and French (1998) also asserted that compounding short-term returns to obtain long-term BHAR better captures longterm investor experience. In fact, using solely the average abnormal returns used in the CAR approach does not precisely measure returns to investors over the long-run period. To perform the analysis, the study employs the STATA Module.

The three-year holding period return is evaluated by computing the compounded monthly buy-and-hold return for acquirer companies, for time $t$ as follows:

$$
B H R_{j T}=\left[\prod_{t=1}^{T}\left(1+r_{j t}\right)\right]-1
$$

Where, $r_{j t}$ is the actual monthly return on the share of $j$ in event period of $t$. $T$ is designated as the number 
of months in event period $t$. The condition measures the total return from a buy-and-hold strategy where a share is purchased at the closing market price and held until $6,12,18,24,30$ and 36 months following the listing date for the full sample of acquirer companies.

The buy-and-hold returns, $B H R_{m T}$ for the market benchmarks, represented by the EWI and VWI for the Tadawul are:

$$
B H R_{m T}=\left[\prod_{t=1}^{T}\left(1+r_{m t}\right)\right]-1
$$

$r_{m t}$ is the corresponding monthly index level of SASEWI and SAS-VWI in event period t. Note that SASEWI denotes the Saudi Arabia all shares equal weight index, and SAS-VWI represents the Saudi Arabia all shares value weight index. The market-adjusted buyand-hold abnormal returns for each security or company in the sample in event period $t$ are computed as:

$$
B H A R_{j t}=\left[\prod_{t=1}^{T}\left(1+r_{j t}\right)\right]-\left[\prod_{t=1}^{T}\left(1+r_{m t}\right)-1\right]
$$

Where $B H A R_{j t}$ is the buy-and-hold abnormal return of security of $j$ in event period of $t$. This allows us to measure the market-adjusted buy-and-hold abnormal returns earned by investors over the $6,12,18,24,30$ and 36 months following the completion month of M\&A events. The test-statistic for the market-adjusted monthly buy-and-hold abnormal returns, $B H A R_{\left(t_{1}, t_{2}\right)}$ during the clustering period from $t_{1}$ to period $t_{2}$, is calculated as:

$$
t=\frac{\overline{B H A R}_{\left(t_{1}, t_{2}\right)}}{\sigma\left(B_{H}\right) / \sqrt{T}}
$$

Where, $\overline{B H A R}_{\left(t_{1}, t_{2}\right)}$ is the market-adjusted monthly average buy-and-hold abnormal return from period $t_{1}$ to period $t_{2}$; and $\sigma\left(B H A R_{t}\right)$ is the standard deviation of market-adjusted monthly buy-and-hold abnormal return in event period of $t$; and $T$ is the total number of acquirer companies in the sample.

\section{RESULTS}

Figure 1 presents descriptive statistics of M\&A events that occurred in the Kingdom of Saudi Arabia from 1998-2017. Figure 1 plots the number of transactions and the dollar value of transactions, in millions dollar of US by year. The M\&A events by Saudi Arabian listed companies began in the late 1990s. Out of 72 cases, $36.11 \%$ of the M\&A announcements occurred during the period 2006-2008, in tandem with the development of the Saudi Arabia capital market. These events reached their peak in the year 2007, with twelve (12) completed transactions of M\&A, however, declined slightly after 2007 during the onset of global financial crisis.

Table 1 outlines the percentage market-adjusted BHAR for the cash and mixed payment of acquisitions in the 36 months holding period following the completion of M\&A. Using the SAS-EWI, evidence shows that cash payment of merger and acquisitions generate market-adjusted returns higher than the mixed payments, an average of 15.18 percent $(\mathrm{t}=3.73$, $p<0.01)$ compared to 10.12 percent $(t=-2.73, p<0.01)$

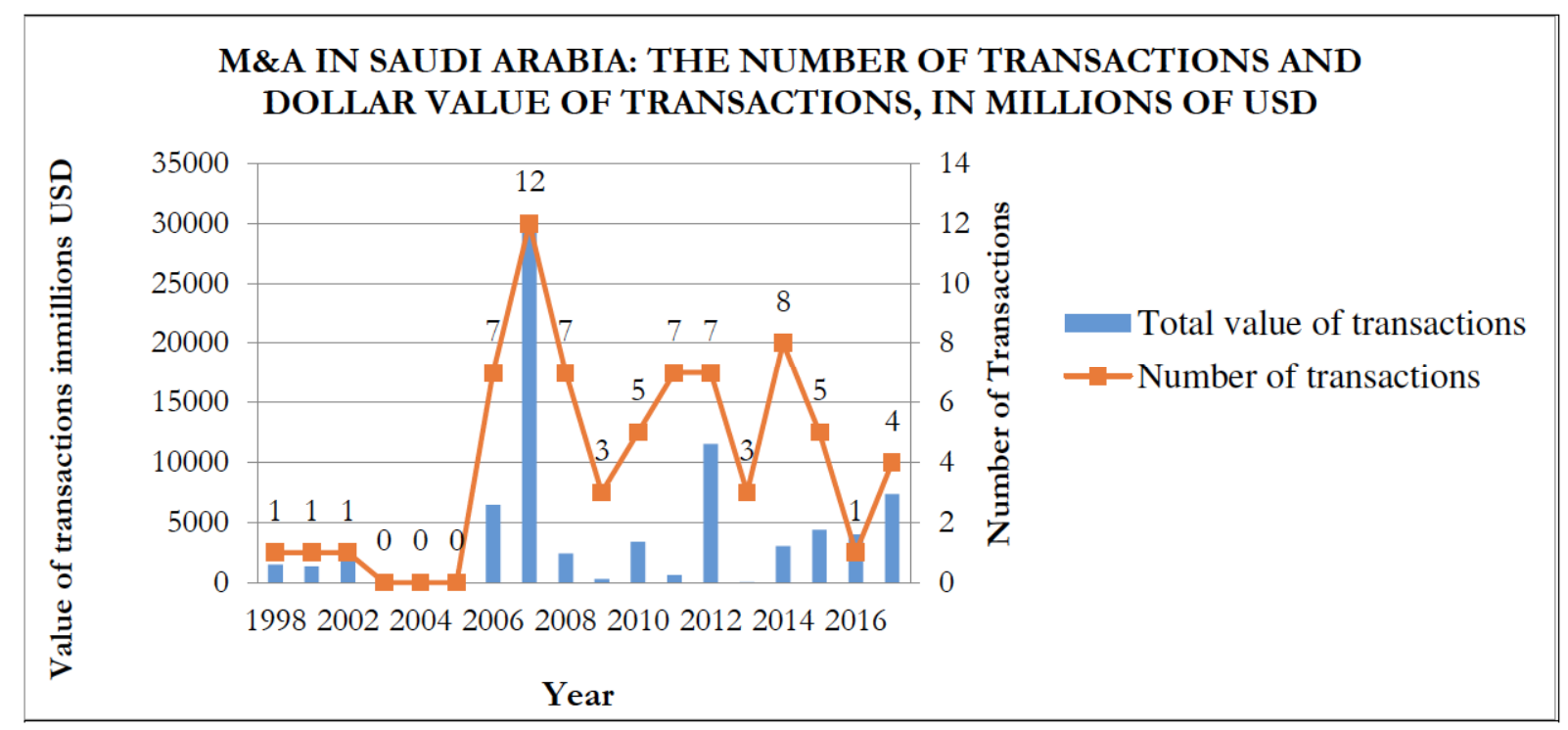

Figure 1: The number of transactions and dollar value of transactions, in millions of US Dollar. 
Table 1: Average Market-Adjusted Buy-and-Hold Abnormal Returns for the Acquirer Companies

\begin{tabular}{|c|c|c|c|c|c|c|c|c|c|c|c|c|}
\hline \multicolumn{13}{|c|}{ Average Market-Adjusted Buy-and-Hold Returns for Acquirer Companies listed on the Tadawul } \\
\hline \multirow[t]{3}{*}{$\begin{array}{l}\text { Market } \\
\text { Indices }\end{array}$} & \multicolumn{6}{|c|}{ SAS-EWI } & \multicolumn{6}{|c|}{ SAS-VWI } \\
\hline & \multicolumn{12}{|c|}{ Months After the Completion of Mergers and Acquisitions } \\
\hline & 6 & 12 & 18 & 24 & 30 & 36 & 6 & 12 & 18 & 24 & 30 & 36 \\
\hline Panel A: & \multicolumn{12}{|c|}{ Cash Payment } \\
\hline BHARs (\%) & 15.18 & 15.00 & 20.28 & 30.74 & 39.83 & 34.53 & 9.20 & 12.51 & 17.85 & 27.84 & 38.34 & 33.50 \\
\hline T-Stat & $3.73^{\mathrm{a}}$ & $1.93^{\mathrm{c}}$ & $1.69^{c}$ & $1.99^{c}$ & $2.58^{\mathrm{b}}$ & $2.68^{b}$ & $2.19^{b}$ & $1.70^{\mathrm{a}}$ & 1.56 & $1.85^{\mathrm{a}}$ & $2.39^{b}$ & $2.42^{b}$ \\
\hline Sig MWRT & $* * *$ & * & & & & $* *$ & & $* * *$ & & $* * *$ & & * \\
\hline Panel B: & \multicolumn{12}{|c|}{ Non Cash Payment } \\
\hline BHARs (\%) & 10.12 & 14.30 & 11.07 & 15.06 & 21.08 & 21.00 & 6.33 & 8.39 & 6.65 & 8.88 & 17.18 & 6.33 \\
\hline T-Stat & $2.73^{\mathrm{a}}$ & $1.84^{\mathrm{b}}$ & 0.92 & 1.06 & 1.39 & $1.88^{\mathrm{c}}$ & 1.44 & 1.12 & 0.58 & 0.65 & 1.13 & 1.51 \\
\hline Sig MWRT & $* * *$ & * & & & & $* *$ & & & & & & \\
\hline
\end{tabular}

Note: Average market-adjusted buy-and-hold abnormal returns for shares within a portfolio are calculated for periods of $6,12,18,24,30$ and 36 months following the completion months of mergers and acquisitions for companies listed on Saudi Arabia Stock Exchange (Tadawul) against the SAS-EWI and SAS-VWI benchmarks. SAS-EWI denotes the Saudi Arabia All Shares-Equal Weight Index. SAS-VWI denotes the Saudi Arabia All-Shares Value Weight Index. a, b and c indicates a statistical significance at the $1 \%, 5 \%$ and $10 \%$ levels, using a two-tailed test. Using the non-parametric Mann-Whitney Rank Test (MWRT) *, ** and *** represent the significant difference between the abnormal returns of large acquirer companies and small acquirer companies at the $10 \%, 5 \%$ and $1 \%$ levels, respectively. SIG denotes the significance value. Panel A divides the acquirer companies into cash payment and non-cash payment.

for the six-month period, 15.00 percent $(t=1.93, p<$ $0.10)$ compared to 14.30 percent $(t=1.84, p<0.10)$ for the twelve-month period, 20.28 percent $(t=1.69$, $\mathrm{p}<0.10)$ compared to 11.07 percent $(t=0.92$, $p=$ insignificant) for the eighteen-month period, 30.74 percent $(t=1.99, p<0.10)$ compared to 15.06 percent $(t=1.06, \quad p=$ insignificant) for the twenty-four-month period, 39.83 percent $(t=2.58, p<0.05)$ compared to 21.08 percent $(t=1.39, p=i n s i g n i f i c a n t)$ for the thirtymonth period, 34.53 percent $(t=2.68, \quad p<0.05)$ compared to 21.08 percent $(t=1.39, p=$ insignificant) for the thirty-six-month period. The difference in abnormal returns between the two sub-samples is statistically significant at $1 \%$ for one-year period, $5 \%$ for the twoyear period (as shown in the SAS-EWI). Overall, evidence indicates that investors could earn abnormal returns if they invest in the cash payment merger relative to its counterpart in the non-cash payment over the three-year holding periods. Notably, our finding sit alongside with evidence put forward by Myers and Majluf (1984), Fishman (1989), Franks et al. (1987), Andrade et al. (2001), and Loughran and Vijh (1997) and Fuller et al. (2002).

\section{CONCLUSION}

Our findings inform the real world debate on corporate M\&A with particular reference to long-run market inefficiency. Over the subsequent 36 months, the acquirer companies' shares for the cash payment method continues to outperform their counterparts of non-cash payment against both market benchmarks. Hence, the study strongly recommends that investors should refine their shares in the portfolio by investing in the cash payment acquirer's shares to assure the investment and to yield abnormal return over the longrun period. The findings also have produced evidence that might provide valuable insight for practitioners, especially fund managers and other investors. There are abnormal return opportunities that may be exploited by investors in the three-year holding period following the completion of M\&A events, hence producing evidence that the Saudi Arabia share market is inefficient. Fund managers can create equity-based mutual fund portfolios, while hedge fund managers can use this approach as one of their tools for risk management. This study is limited to Tadawul only; thus, it cannot be generalized to other share markets in the region. Future studies should measure and compare the short-and-long run performance of $M \& A$ companies across GCC and MENA region to further support our findings on the emerging markets.

\section{REFERENCES}

Agrawal, A., \& Jaffe, J. F. (2000). The post-merger performance puzzle. In Advances in Mergers and Acquisitions (Vol. 1, pp. 7-41): Emerald Group Publishing Limited. https://doi.org/10.1016/S1479-361X(00)01002-4

Andrade, G., Mitchell, M., \& Stafford, E. (2001). New Evidence and Perspectives on Mergers. Journal of Economic Perspectives, 15(2), 103-120. https://doi.org/10.1257/jep.15.2.103 
Andre, P., Kooli, M., \& L'Her, J.-F. (2004). The Long-Run Performance of Mergers and Acquisitions: Evidence from the Canadian Stock Market. Financial Management, 33(4).

Barber, B. M., \& Lyon, J. D. (1997). Detecting long-run abnormal stock returns: The empirical power and specification of test statistics. Journal of Financial Economics, 43(3), 341-372. https://doi.org/10.1016/S0304-405X(96)00890-2

Berkovitch, E., \& Narayanan, M. P. (1990). Competition and the Medium of Exchange in Takeovers. The Review of Financial Studies, 3(2), 153-174. https://doi.org/10.1093/rfs/3.2.153

Dowling, M., \& Vanwalleghem, D. (2018). Gulf Cooperation Council cross-border M\&A: Institutional determinants of target nation selection. Research in International Business and Finance, 46, 471-489. https://doi.org/10.1016/j.ribaf.2018.06.004

Dutta, S., \& Jog, V. (2009). The long-term performance of acquiring firms: A re-examination of an anomaly. Journal of Banking \& Finance, 33(8), 1400-1412. https://doi.org/10.1016/j.jbankfin.2009.02.004

Dutta, S., Saadi, S., \& Zhu, P. (2013). Does payment method matter in cross-border acquisitions? International Review of Economics \& Finance, 25, 91-107. https://doi.org/10.1016/j.iref.2012.06.005

Fama, E. F. (1970). Efficient Capital Markets: A Review Of Theory And Empirical Work. The Journal of Finance, 25(2), 383-417. https://doi.org/10.1111/j.1540-6261.1970.tb00518.x

Fama, E. F., \& French, K. R. (1998). Value versus Growth: The International Evidence. The Journal of Finance, 53(6), 19751999. https://doi.org/10.1111/0022-1082.00080

Fishman, M. J. (1989). Preemptive Bidding and the Role of the Medium of Exchange in Acquisitions. The Journal of Finance, 44(1), 41-57. https://doi.org/10.2307/2328274

Franks, Harris, R., \& Mayer, C. (1987). Means of Payment in Takeovers: Results for the UK and US. https://doi.org/10.3386/w2456

Franks, Harris, R., \& Titman, S. (1991). The postmerger share-price performance of acquiring firms. Journal of Financial Economics, 29(1), 81-96. https://doi.org/10.1016/0304-405X(91)90014-B

Fuller, K., Netter, J., \& Stegemoller, M. (2002). What Do Returns to Acquiring Firms Tell Us? Evidence from Firms That Make
Many Acquisitions. The Journal of Finance, 57(4), 17631793.

https://doi.org/10.1111/1540-6261.00477

Goergen, M., \& Renneboog, L. (2004). Shareholder Wealth Effects of European Domestic and Cross-border Takeover Bids. European Financial Management, 10(1), 9-45. https://doi.org/10.1111/j.1468-036X.2004.00239.x

Hansen, R. G. (1987). A Theory for the Choice of Exchange Medium in Mergers and Acquisitions. The Journal of Business, 60(1), 75-95. https://doi.org/10.1086/296386

Ismail, A. (2008). Which acquirers gain more, single or multiple? Recent evidence from the USA market. Global Finance Journal, 19(1), 72-84. https://doi.org/10.1016/j.gfj.2008.01.002

Loughran, T., \& Vijh, A. M. (1997). Do Long-Term Shareholders Benefit From Corporate Acquisitions? The Journal of Finance, 52(5), 1765-1790. https://doi.org/10.1111/j.1540-6261.1997.tb02741.x

Lyon, J. D., Barber, B. M., \& Tsai, C.-L. (1999). Improved Methods for Tests of Long-Run Abnormal Stock Returns. The Journal of Finance, 54(1), 165-201. https://doi.org/10.1111/0022-1082.00101

Moeller, S. B., Schlingemann, F. P., \& Stulz, R. M. (2005). Wealth Destruction on a Massive Scale? A Study of Acquiring-Firm Returns in the Recent Merger Wave. The Journal of Finance, 60(2), 757-782 https://doi.org/10.1111/j.1540-6261.2005.00745.x

Myers, S. C., \& Majluf, N. S. (1984). Corporate financing and investment decisions when firms have information that investors do not have. Journal of Financial Economics, 13(2), 187-221. https://doi.org/10.1016/0304-405X(84)90023-0

Ritter, J. R. (1991). The Long-Run Performance of initial Public Offerings. The Journal of Finance, 46(1), 3-27. https://doi.org/10.1111/j.1540-6261.1991.tb03743.x

Travlos, N. G. (1987). Corporate Takeover Bids, Methods of Payment, and Bidding Firms' Stock Returns. The Journal of Finance, 42(4), 943-963. https://doi.org/10.1111/j.1540-6261.1987.tb03921.x

Yang, J., Guariglia, A., \& Guo, J. (2017). To what extent does corporate liquidity affect M\&A decisions, method of payment and performance? Evidence from China. Journal of Corporate Finance. https://doi.org/10.1016/j.jcorpfin.2017.09.012

\section{DOI: https://doi.org/10.6000/1929-7092.2019.08.59}

(c) 2019 Zakaria et al.; Licensee Lifescience Global.

This is an open access article licensed under the terms of the Creative Commons Attribution Non-Commercial License (http://creativecommons.org/licenses/by-nc/3.0/) which permits unrestricted, non-commercial use, distribution and reproduction in any medium, provided the work is properly cited. 